that there is for potassium salts, and the urgency of finding fresh sources of supply, it cannot be doubted that this subject will receive all the attention that its importance deserves. It would indeed be fortunate if the needs of the British Empire in this respect could be supplied from our great Indian dependency.

H. L.

\section{PROF. H. DEBUS, F.R.S.}

B Y $Y$ the death of Dr. Heinrich Debus, which occurred at his residence in Cassel, Hessen, on December 9, we lose almost the last link which connects us with that notable group of menHerbert Spencer, Darwin, Hooker, Huxley, Tyndall, Williamson, Frankland-who constituted the scientific hierarchy of London in mid-Victorian times. To the younger generation of British chemists, Debus was, probably, personally almost unknown, but up to within a few years ago he was a constant annual visitor to England, and was to be found at his former haunts in the Athenæum and Savile Clubs, or at the tables of such of his old friends as were left to him. But as the years passed the ties which led him to revisit the scenes of his social activities became fewer and fewer until there was scarcely a "kent face" left to him in his clubs or in the tea-room of the Royal Society, and London became nothing more to him than a place of dead friendships and departed memories, and so he ceased to come. A spare man, sharp-featured and clean-shaven, of abstemious habits, regular and methodical in his mode of life, and of a singularly placid and equable disposition, he maintained his mental and physical vigour up to an advanced age, and was able to take his daily walk almost to the last. His mortal illness was quite short, and he passed away peacefully during the night of December 9 , in the ninety-second year of his age.

Debus belonged to a school of chemists of which scarcely a representative remains. A reticent man, and particularly uncommunicative concerning his personal affairs, very little is known of his origin or early history beyond that he was the son of Valentine Debus, and was born in Hessen in July, I824. His earliest instructor in chemistry was Bunsen, who succeeded Wöhler at the Polytechnic School of Cassel in 1836 , and where he remained until 1839, when he was appointed Professor Extraordinarius at Marburg. Debus followed him from Cassel and graduated at Marburg in 1848 . Here he formed the acquaintance of Kolbe, and gained the friendship of Frankland, a circumstance which materially affected his subsequent career, as it led to his coming to England, and his eventual selection as Professor of Chemistry in the Royal Naval College, Greenwich. In Frankland's slight autobiographical sketch, the publication of which we owe to the pious care of his daughters, we read that Debus established a "record" at Marburg, inasmuch as he was the first in that university to hold the "disputation" in German instead of in Latin. What "wrangling" then meant in a GerNo. 24 IO, VOL. 96] man university may be gathered from the follow. ing extract from Frankland's journal, under date November 4,1848 , relative to this event :-

I heard Debus read his discourse and dispute in the University, after which he was fully invested with the title of Ph.D. The Pro-Rector and six professors were present, most of whom, as well as two doctors whom Debus had brought with him, disputed the following theses:-(I) The allotropic condition of matter depends upon differences in the arrangement of atoms; (2) the ferrocyanide compounds are not to be considered as double salts; (3) the opinion of Ettingshausen as to the cause of electrical phenomena is untenable; (4) the unequal heating of the air and the earth is the immediate cause of the greater part of atmospheric electricity; (5) the organic bases are coupled ammonia compounds; (6) the doctrine of polymeric isomorphism is erroneous. ${ }^{1}$ The ceremony of installation lasted above an hour and a half, and at its close Prof. Bunsen delivered an oration on the volcanic phenomena of Iceland.

Frankland, it may be noted in passing, established a further "record" by being the first Englishman to graduate in Marburg; on this occasion the Faculty dispensed with the disputation in the Aula altogether, on the ground, as he says, that being a foreigner, he had not sufficient command of the language, either Latin or German.

Debus's earliest published scientific work, in 1848, was probably inspired by Kolbe, who, after a short sojourn in England, had rejoined Bunsen at Marburg. It consisted of a short paper on the chemistry of madder root, in which the author failed to recognise the nature and mutual relations of alizarin and purpurin; these he termed, respectively, "lizaric acid" and "oxilizaric acid." His next essays were more fortunate, and he published in rapid succession a number of papers on organic sulphur products, and on the oxidation products of alcohol, glycerin, and glycol. His work on glycerinic acid and its salts, on glyoxal, and glyoxylic acid, finds its due place in the chemical history of these substances. Among subsequent papers the most noteworthy are "On the Chemical Theory of Gunpowder," "On the Nature of Wackenroder's Solution," and his controversy with the late Sir Henry Roscoe on the origin of Dalton's atomic theory.

Debus came to this country in $185 \mathrm{I}$, and, like his friend Frankland, was at first engaged in school-teaching, first at Queenwood College and then at Clifton. In 1870 he moved to London, and was attached to the medical school of Guy's Hospital as lecturer on chemistry. On the establishment of the Royal Naval College at Greenwich he was appointed Professor of Chemistry, presumably through the action of his friend Hirst, who was made Director of Studies. Here he remained until the age of retirement compelled him to relinquish the duties of his chair, when he gave up his London residence and again settled in Germany.

Debus joined the Chemical Society in 1859 , and was a vice-president in $1871-4$, but took little share in the management of the society. He was

\footnotetext{
1 In the original the titles of the theses are give $n$ in German.
} 
elected into the Royal Society in $186 \mathrm{I}$, and served on the Council in $1870-72$, and again in $1881-83$. He was a well-read, scholarly man, of sound judgment, and a shrewd judge of character. He was never married, but was very fond of children, with whom he was very popular, in spite of certain peculiarities of manner and speech and little affectations of dress-such as a passion for coloured ties-amiable weaknesses which only served to endear him still more strongly to his many friends. He was an excellent teacher, with a quiet dignity of manner, and a subtle appreciation of humour, with a skill in parrying its shafts, which effectively checked the efforts of the potential Ben Allens and Bob Sawyers at Guy's, or the too exuberant spirits of the young lieutenants of H.M.S. President at Greenwich. He served for three periods-in all fifteen yearsas an examiner in chemistry of the University of London in the old Burlington Gardens days. His sympathy with young men, and his quick discernment of character and merit, together with his experience as a teacher and his wide knowledge of his subject, were excellent qualifications for the position, and he enjoyed the fullest confidence of his colleagues at the famous round-table in the old university buildings.

T. E. T.

\section{NOTES.}

WE notice the names of three fellows of the Royal Society, all of whom are engaged in Government departments, in the list of New Year honours, namely, Dr. Lazarus Fletcher, director of the Natural History Departments of the British Museum, who has been knighted; Col. H. C. L. Holden, assistant director of supplies and transport, War Office, who has been promoted to the rank of K.C.B. ; andSir W.Watson Cheyne, who has received the honour of K.C.M.G. We do not recognise in the list any names of men specifically selected for honours on account of their productive work in scientific fields, but the following may be appropriately recorded here because of their association with such work:-Knights : Dr. Adam Smith, principal and vice-chancellor of Aberdeen University; Dr. G. A. Berry, honorary surgeon-oculist to the King in Scotland, and formerly president of the Royal College of Surgeons, Edinburgh; Dr. T. W. Parkinson, author of works on cancer and tumour; Mr. M. Rees, laryngologist to the King's Household and to Queen Alexandra. K.C.M.G. : Sir James Porter, honorary physician to the King. K.C.V.O.: Sir A. A. Bowlby, surgeon in ordinary to the King. C.M.G.: Dr. J. Cadman, professor of mining in the University of Birmingham. C.B.: Col. C. P. Martel, superintendent, Royal Gun and Carriage Factory, Woolwich Arsenal; Mr. A. W. J. MacFadden, Chief Inspector of Foods, Local Government Board.

IN reply to questions asked by $\mathrm{Mr}$. Lynch in the House of Commons on January 4, Mr. Asquith said that every endeavour continues to be made to organise and utilise all the available scientific ability of the country in the most efficient way with the view of coping with problems introduced by the war. The No. 24 IO, VOL. 96] activities of the scientific committees have been by no means limited to criticism and advice with regard to suggestions and inventions sent in from outside. Mr. Asquith also said that a body of scientific workers is definitely charged with the study of actual war conditions, that is, to examine, devise, or invent appliances which may be helpful to the Allies in the tield.

THE Government of British Columbia has presented to the Royal Botanic Gardens, Kew, a magnificent spar of Douglas fir to replace the old flagstaff which was taken down in I913 owing to decay. The suggestion to present a really fine specimen of a Douglas spar was made by Mr. J. H. Turner, the late AgentGeneral for British Columbia, and was readily taken up by the Premier and the Government of British Columbia. This suggestion, made in the autumn of I913, has now definitely materialised, and the spar, which was loaded on to the R.M.S. Merionethshire in August, 1915, arrived in the Thames at the close of last year, and was moored in the river off Kew Gardens on January 3. The spar was logged from the lower mainland coast of British Columbia. The tree selected measured $220 \mathrm{ft}$. in length, $6 \mathrm{ft}$. in diameter at the large end, and 18 in. in diameter at the small end. The $\log$ was loaded on a logging railway and hauled ten miles to salt water, being taken by a tug to Vancouver. There it was hewn to its final shape, making it $215 \mathrm{ft}$. in length, $33 \mathrm{in}$. at the butt, and 12 in. at the top. Its weight is about 18 tons. The spar was brought from British Columbia on the deck of the Merionethshire, and its loading was accomplished with some difficulty. Its erection in the Royal Botanic Gardens will be an operation of considerable magnitude.

We much regret to note the death of Dr. George Oliver, of Riversleigh, Farnham. He was a man of very great ability and extraordinary energy. Although for thirty-five years he was engaged in a very large and exacting practice at Harrogate, he yet found time to make most valuable researches on the circulation of the blood. He was one of the first to take up the question of the pressure of blood in the arteries, and the instrument he invented for the purpose of measuring the arterial tension in man was only surpassed in ingenuity by his arteriometer for measuring the actual diameter of the artery. He also invented an ingenious instrument for measuring the amount of hamoglobin in the blood. With these instruments he made many important observations, which he embodied in two works, "Blood and Blood Pressure" and "Studies in Blood Pressure," works which were both of scientific interest and practical value in treatment. Along with Sir Edward Schäfer he examined the action of the extract of suprarenal glands and proved it to be simply enormous. This observation is one of fundamental importance in regard to the physiological problem of how the blood pressure in the living body is maintained in equilibrium. Dr. Oliver was a gold medallist of the University of London, and Croonian lecturer in 1896 at the Royal College of Physicians, of which he was a fellow. He established the OliverSharpey lectureship at the Royal College of Physicians in memory of his old teacher, Prof. William Sharpey, 